\title{
TEACHING ENGLISH VOCABULARY USING PICTURE IN EIGHTH GRADE OF JUNIOR HIGH SCHOOL
}

\author{
Restu Anggi Winita, Fairuz Sopiya Rasyida \\ ${ }^{1}$ IKIP Siliwangi Bandung \\ ${ }^{2}$ IKIP Siliwangi Bandung \\ ${ }^{1}$ restuanggiwnita@yahoo.com, ${ }^{2}$ fairuz.sopiya@yahoo.co.id
}

\begin{abstract}
This research focused with teaching English vocabulary using picture in eight grade of junior high school. This research explores the implementation of English vocabulary and to find out the score improvement in using picture in learning process. The objective of this research is to find out the effectiveness of picture in improving students' vocabulary. Data collection technique focus on pretest and posttest. Picture is a good media to make everything like real and can visualize to the lesson environtment. The means score of pretest was 42.33 and the posttest get improve to 76.50. It could also be concuded that teaching English vocabulary using picture was effective media to improve students' vocabulary.
\end{abstract}

Keywords: vocabulary, picture, media

\section{INTRODUCTION}

In Indonesia, English is taught as a compulsory subject in secondary school including Junior High School and Senior High School even up to College level, because the government considers that mastering English is one way to absorb the sciences and technology in order to create great human resource.

To knowing English as great as native speaker the basic is understanding the vocabulary. Decarrico (2001: 285) Vocabulary learning is central to language acquisition, wheter the language is first, second or foreign. To learn English we must know the meaning of word, in English many words mean different. To decide how many words to teach and to learn many researchers that learners should initially be taught a large productive vocabulary at least two thousand high frequency words, but in Indonesia we only learn English at school.

School is the best place to make students understand about English vocabulary because they will learn about everything that relate to the material. In this journal we teach the vocabulary using picture. According to Herrell and Jordan (2004:19) picture is an approach in which the language used in instruction is made more understandable by the display of drawings or photographs that allow students to hear English words and connect them to the visual images being displayed.

\section{Research Question}

The writer need to understanding the problem with this research on the following research question: Is picture can improve students' vocabulary? 


\section{Hypothesis}

The hypothesis in this research:

$\mathrm{H}_{0}$ (null hypothesis):

"Picture is not effective media in improving students' vocabulary"

Ha (alternative hypothesis):

"Picture is effective media in improving students' vocabulary"

\section{LITERATURE REVIEW}

Language is the way to communicate to each other and language is formed of words. Vocabulary is a basic thing to understanding about English and vocabulary relate to acquisition of second language. Based on Seal (1991: 298) the technique after we teach using picture is convey meaning, check understanding and consolidate the vocabulary.

Paquot (2010: 10) state that type of vocabulary are:

1. Core vocabulary is consists of words that are of high frequency in most uses of the language, that comprises the most useful function words ( $a$, about, be, by, do, he, I, and to) and content words (bag, person, put and suggest).

2. Academic vocabulary is the specific vocabulary for students in higher education settings and the most widely used today in language teaching, testing and the development of pedadogical material.

3. Technical terms or domain-specific are words whose meaning requires scientific knowledge.

4. Fuzzy vocabulary categories is the boundaries between core vocabulary, academic vocabulary, and technical terms.

We teach English vocabulary using picture as a media. According to Georgiou and Pavlou (2003: 110) picture has aims to enable the children to develop criteria regarding their knowledge of English and to motivate the by providing a visual representation of their knowledge and by picture the student can look at and comment on their pictures whenever they add an item.

Based on Herrell and Jordan ( 2004: 19) the steps in planning and implementing visual scaffolding are:

1. Identifying the vocabulary

2. Collecting visuals

3. Reproducing and organizing visuals

4. Engaging students

5. Building the file

We use testing production ability with pictures. We give a test with the objects drawn below. According to Hughes (2003:182) This method of testing vocabulary is obviously restriced to concrete nouns that can be unambiguously drawn.

\section{METHOD}

The research used quantitative as method and pre experimental as design. According to Blaxter, Hughes and Tight (1996: 60) Quantitative research is the term suggests, concerned with the collection and analysis of data in numeric form. Quantitative research tends to emphasize relatively large-scale and representatives sets of data, and is often, falsely in our view, presented or perceived as being about the gathering of facts". This research used pre experimental as design. The writer used one group pretest and posttest design. 
Here is the design of pre experimental. (Anthony et al 2016: 19)
(O1
Pretest
$\mathrm{X}$
treatment
$\mathrm{O} 2)$
posttest

\section{Subject of the Research}

In this research, we took the eighth grade students of one junior high school in Cimahi were taken as population. Besides, sample is part of the population which is used as the source of the real data of the research. 8A class was used to be sample of the research.There were 30 students, 14 boys and 16 girls students.

\section{Data Collection and Data Analysis}

In this research, the research collected the data by using pretest and posttest. Pretest was implemented to find out the students' ability in vocabulary before the treatment. Then, the writer did some treatments and role play technique was used as treatments. After treatment, the posttest was done to know the effect of using picture in teaching vocabulary comprehension. The data gathered from test were analyzed by using SPSS 21 and interpreted to know the students progress in vocabulary comprehension through picture.

\section{RESULTS AND DISCUSSION}

This part displays the analysis and interpretation the data which have been collected by using pretest and posttest.

Table 1. The result of pretest and posttest

\begin{tabular}{cccc}
\hline No & Name & Pretest Score & Posttest Score \\
\hline 1 & Student 1 & 25 & 75 \\
\hline 2 & Student 2 & 70 & 95 \\
\hline 3 & Student 3 & 60 & 60 \\
\hline 4 & Student 4 & 55 & 95 \\
\hline 5 & Student 5 & 20 & 70 \\
\hline 6 & Student 6 & 25 & 80 \\
\hline 7 & Student 7 & 40 & 70 \\
\hline 8 & Student 8 & 15 & 50 \\
\hline 9 & Student 9 & 30 & 65 \\
\hline 10 & Student 10 & 60 & 70 \\
\hline 11 & Student 11 & 25 & 70 \\
\hline 12 & Student 12 & 20 & 55 \\
\hline 13 & Student 13 & 30 & 80 \\
\hline 14 & Student 14 & 40 & 70 \\
\hline 15 & Student 15 & 40 & 85 \\
\hline 16 & Student 16 & 45 & 70 \\
\hline 17 & Student 17 & 50 & 60 \\
\hline 18 & Student 18 & 20 & 75 \\
\hline 19 & Student 19 & 30 & 80 \\
\hline 20 & Student 20 & 25 & 70 \\
\hline & & & \\
\hline
\end{tabular}


172 Winita, Rasyida. Teaching English Vocabulary Using Picture In Eighth Grade Of Junior High School

\begin{tabular}{llll}
\hline 21 & Student 21 & 50 & 90 \\
\hline 22 & Student 22 & 60 & 95 \\
\hline 23 & Student 23 & 35 & 85 \\
\hline 24 & Student 24 & 65 & 85 \\
\hline 25 & Student 25 & 70 & 90 \\
\hline 26 & Student 26 & 50 & 80 \\
\hline 27 & Student 27 & 65 & 85 \\
\hline 28 & Student 28 & 45 & 90 \\
\hline 29 & Student 29 & 35 & 70 \\
\hline 30 & Student 30 & 70 & 80 \\
\hline
\end{tabular}

Table 2. Normality test

Tests of Normality

\begin{tabular}{lrrrrrrr}
\hline & \multicolumn{3}{c}{ Kolmogorov-Smirnov $^{\mathrm{a}}$} & \multicolumn{4}{c}{ Shapiro-Wilk } \\
\cline { 2 - 9 } & Statistic & df & Sig. & Statistic & df & \multicolumn{1}{c}{ Sig. } \\
\hline Pretest &, 129 & 30 &, $200^{*}$ &, 935 & 30 &, 068 \\
Posttest &, 141 & 30 &, 133 &, 956 & 30 &, 247 \\
\hline
\end{tabular}

*. This is a lower bound of the true significance.

a. Lilliefors Significance Correction

Criteria:

If $\mathrm{Sig}>0.05$

The sample was normal distribution.

Pretest : $\quad$ Sig $0.187>0.05$

The sample was normal distribution

Posttest: $\quad$ Sig $0.108>0.05$

The sample was normal distribution

We look to Kolmogorov-Smirnov because the sample is less than 33 .

Table 3. Paired Samples Statistics

Paired Samples Statistics

\begin{tabular}{|c|c|c|c|c|c|}
\hline & & Mean & $\mathrm{N}$ & Std. Deviation & Std. Error Mean \\
\hline \multirow{2}{*}{ Pair 1} & Pretest & 42,33 & 30 & 17,257 & 3,151 \\
\hline & Posttest & 76,50 & 30 & 11,901 & 2,173 \\
\hline
\end{tabular}

We can look the mean of pretest 42.33 and the mean of posttest 76.50 it means the score was improve from using picture than before. 
Table 4. Paired Samples Statistics

Paired Samples Test

\begin{tabular}{|c|c|c|c|c|c|c|c|c|c|}
\hline & & \multicolumn{5}{|c|}{ Paired Differences } & \multirow[t]{3}{*}{$\mathrm{t}$} & \multirow[t]{3}{*}{ df } & \multirow{3}{*}{$\begin{array}{l}\text { Sig. (2- } \\
\text { tailed) }\end{array}$} \\
\hline & & \multirow[t]{2}{*}{ Mean } & \multirow[t]{2}{*}{$\begin{array}{c}\text { Std. } \\
\text { Deviation }\end{array}$} & \multirow[t]{2}{*}{$\begin{array}{l}\text { Std. Error } \\
\text { Mean }\end{array}$} & \multicolumn{2}{|c|}{$\begin{array}{l}95 \% \text { Confidence Interval } \\
\text { of the Difference }\end{array}$} & & & \\
\hline & & & & & Lower & Upper & & & \\
\hline $\begin{array}{l}\text { Pair } \\
1\end{array}$ & $\begin{array}{l}\text { Pretest - } \\
\text { Posttest }\end{array}$ & $-34,167$ & 14,860 & 2,713 & $-39,716$ & $-28,618$ & $-12,593$ & 29 & ,000 \\
\hline
\end{tabular}

Criteria:

If Sig $>0.05$

$\mathrm{H} 0$ is accepted

If Sig. $<0.05$

$\mathrm{HO}$ is rejected

The result Sig. $0.000<0.005$ so, the null hyphothesis was rejected and the alternative hypothesis was accepted.

\section{CONCLUSION}

This research was effective in improving student's vocabulary by using pictures. In addition, the students were more active and participated in teaching learning process of vocabulary. Therefore, using picture can be alternative strategy for teacher in teaching vocabulary which can improve and keep their vocabulary. It can be proved from the following fact. Relate to the data of SPSS that significance value (.00) was lower than the significance level (.05) so the picture is an influence media to improve English vocabulary.

\section{ACKNOWLEDGMENTS}

Thank to Allah SWT for blessing in finishing this article, and also be thankful to head of IKIP Siliwangi Bandung, head of English education study program and as the supervisor who has given guidance, advices, corrections, and suggestion in completing this article.

\section{REFERENCES}

Anthony D. Harris, MD, MPH Jessina C. McGregor, PhD Eli N. Perencevich, MD, MS Jon P. Furuno, PhD Jingkun Zhu, MS Dan E. Peterson, MD, MPH Joseph Finkelstein, MD. (2016). The Use and Interpretation of Quasi-Experimental Studies in Medical Informatics. JAMIA, 16-23.

Celce-Murcia, M. (1991). Teaching English as a Second or Foreign Language. University of California, Los Angeles: Heinle\&Heinle.

Decarrico, J. S. (2001). Teaching English as a Second or Foreign Language. United States of Amerika: Heinle\&Heinle.

Hudson, T. (2007). Teaching Second Language Reading. New York: Oxford University Press. 
174 Winita, Rasyida. Teaching English Vocabulary Using Picture In Eighth Grade Of Junior High School

Hughes, A. (2003). Testing for Language teacher. New York: Cambridge University Press.

Jordan, A. H. (2004). Fity Strategies For Teaching English Language Learners. California State University, Fesno: Person Longman.

Loraine Blaxter, Christina Hughes, Malcolm Tight. (1996). How to Research . London: Open University Press.

Murcia, M. C. (1991). Teaching English as a Second or Foreign Language. University of California, Los Angeles: Heiline\&Heiline.

Paquot, M. (2010). Academic Vocabulary in Learner Writing. New york: International Publishing Group.

Pavlou, S. 1.-G. (2003). Assesing Young Learners. New York: Oxford University Press. 